中にシステム設計に heuristical な手法を導入するとい う論文があったように記㥁するが， heuristics を用いた 学留設計などを計算機にやらせることは今後大いに研究 されるべきではないかと考える。大変困難な問題たとはは 思施。

\section{ま と め}

C. A.D. の現状は省力化の点で大きな効果を上げてお り，最適化すある程度まで可能になっている。これらの 奻果はクラフィック・ディスブレイ，自動製戝など計算 機と人間との間の通信方式の進歩に伴なっていよい上增 大して行くすのと思われる。大島氏のいわれる技術設計 の部分は遠からず，全面的に計算機に委ねられてしまう ことになるであろら。一方工学設計の部分は大島氏のい われるように設計者の個性が出て来る部分ではあるが， たとえば学習設計のような概念が C. A. D. 汇導入され るようになるとこの部分をもかなり計算機が分担する ことになるのではなかららか。すちろん学習設計といっ てもそのブログラム自体は人間が栲えるのであるから， プグラムを通して人間の個性はやはり生きていること になるであるら。たた現状では人間自身が学習する方が 能率が良いために人間が工学設計を行なっているのであ
るから，計算機の学習の方が能率が良くなってからでな いと学習設計はあまり意味がないことになろう。

感想

シンボジゥムという言葉の意味を辞書によって調へて みると“㗽宴（古代ギリシャで通例会食に続いて行なわ れた酒をくみかわしながら音楽を楽しみ談論に興じたつ どい)”とあり, 元来非常に気楽倓論を交わす催しだ ったようである。ところが学会のシンポシウムといらの は時間が限られ，人数もかなり多く，またかなり形式ば ったムードああって，自由な討論を盛り上げることはな かなか難かしい。本セッションも座長の運営がよろしき を得なかったことにるよるが，討論が今一つ盛上がら ず,とくに発言が講演者および共著者だけであったこと は残念であった。

なお講演前刷集について著者からつぎの正誤表が提出 されたので訂正されたい。

\begin{tabular}{|c|c|c|c|}
\hline 面 & 行 & 誤 & 正 \\
\hline 88 & 下 8 & 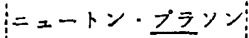 & $=2-$ \\
\hline 89 & 上 6 & を短縮される & を短縮させる \\
\hline 91 & 文献（18） & $196 \underline{6}$ & $196 \underline{9}$ \\
\hline
\end{tabular}

\title{
[Session 4]＼cjkstart相平衡およびその他物性の相関ならびに推算*
}

\section{1月20日 (木)：B会場}

\section{寞 長 佐藤一雄***.中西浩一郎**** . 石田清春**}

午前中佐藤先生の司会で展望を中西先生に講演してい ただき，続いて拡散係数関係 2 件と相平衡に関する話題 を提供された椿氏の発表と抁散係数に関する質疑応答を 行ない, 関西大学の福島䕮氏よりスライドを使用して払 散係数に関するコネントをいただいた。午後は石田の司 会で相平衡関係 4 件の講演と質疑応答を行なったが，午 前・午後にわたり約 50 名の参加者は熱心に討論に加わ られ，この方面への関心の深さが伺われた。たた，大学 関係の先生方で数十名す欠席されたため，このセッショ

\footnotetext{
* 昭和 44 年12月20日受理

* Kiyoharu Ishida 觧周大学工学部

*** Kazuo Sato 東京理科大学

**** Koichiro Nakanishi 京都大学工学部
}

\section{石田清 春**}

ソにも幾分参加者が少なくなったことは時節柄とはいえ 残念なことであった。受付けられた質問票が最も多かっ たのも特色の一つであった。

\section{4-1 展望（中西・石田）}

液相中の拡散係数の推算法における基礎的問題は（1） 無限希釈における拡散係数 $D_{1(2)}$ の推算と（2）溶質濃度 が高いとさの相互拡散係数 $D_{12}$ の推算とに帰せられよ ら。一方, 実際の化学工学的諸操作において液相中の物 質移動を取扱ら際には，一般に混合溶媒中に微量に存在 する分子種の拡散係数が問題になる。これは三成分系拡 散の特別な場合の一つとして，溶液が会合性でない場合 
には二成分系データからの推算が可能であるが, 実際に は水溶液である場合が多く，他の成分が塩であれ，有機 液体であれ，水との相互作用による複雑な举動が見られ る。ことに高分子溶液の場合にはその極端な場合の一つ として常識的な考え方を改めざるを得ないようである。

相平衡の推算においては問題は如何にしてフガシチま たは活量を正しく求めるかに州着する。現在のところ, 高压においては状態方程式や対応状態原理を混合物に応 用して気相と液相のフガシチを求め，それより平衡関係 を計算すること，また低圧においては理想性からの偏倚 を表わす活量係数を組成の関数として与える際，より精 度の高い式を見出すこと,および定数の推算法を確立す ることなどの点が中心的課題になっているようである。 純粋成分の物性値のみで精度よく推算することは困難 なので，測定容易な実測値を一つでむ少なく使用して全 般の関係を精度よく推算しよらとする方向に向っている ように思われる。複雑な式や系を取报おうとすれば必然 的に計算が繁雑となる。複雑な計算が可能となったのは 近年の電子計算機の急速な発達, 普及に負らところが大 きいか，種々の問題が残されていて，推算法を如何に合 理的に計算機にのせるかる重要な問題の一つであろう。

\section{4-2 各種塩類水溶液における気体の抎散係数につい て（名大·工 恩田格三郎·佐田栄三・小林 猛} ·安藤則夫・鬼頭繁治)

$\mathrm{NH}_{4} \mathrm{Cl}$ など 17 種の程頑水溶液中における $\mathrm{CO}_{2}$ の払 散係数を $5,15,25^{\circ} \mathrm{C}$ において夜柱塔による四収法によ り測定しここの結果を用いて溶液粘度の瀑度俰数を利用 した拡散係数の推算法を提出した。これらの塩類水溶液 はいわゆる負粘度 (negative viscosity) を示すむのであ って, 濃度の增加とともに粘度が一度減少し極小点を持 つ。この性質を表わす式として著者らは次式を用いた。

$$
\mu / \mu_{0}=1+A \sqrt{C}+B C+F C^{2}
$$

ここに, $\mu, \mu_{0}$ は溶液および溶媒の粘度, $C$ は濃度, $A$, $B, F$ は定数である。たたし, 実騟の濃度範囲では $A \sqrt{C}$ は無限小となるので, 定数 $B, F$ のみを䇛験的に求めた。 ついで Jones-Dole（1929）の考え方にならい，拡散係数 の推算式として次式を提出した。

$$
D_{0} / D=1+k_{1} B C+k_{2} F C^{2}
$$

ここに， $D_{0}, D$ は溶媒および溶液中の桩散係数， $k_{1}, k_{2}$ は塩の種類、濃度および温度によらない定数である。

前記の実験データを用いて上式中の係数 $k_{1} と k_{2}$ を最 小自乘法により決定し， $k_{1}=0.669 ， k_{2}=0.412$ を得てい る。この式は著者らの測定データと平均誤差 $3 \%$ 以内で 一致し, また Gubbins ら（1966）による塩類水溶液中の $\mathrm{H}_{2}$ または $\mathrm{CH}_{4}$ の拡散係数の測定値とも15\% 以内で一
致する。

兵問 1. 佐藤（東理大）定数 $k_{1}, k_{2}$ は $\mathrm{CO}_{2}$ に固有 のものか。

答 他のガスについては検討中です。

問 2. 佐藤（東理大） $\mathrm{CO}_{2}$ と反応する $\mathrm{BaCl}_{2}$, $\mathrm{CaCl}_{2}, \mathrm{MgCl}_{2}$ などでる他の塩類と違ったところは認め られないか。

答 実験では認められなかった。多分大丈夫と思ら。

算問 3. 星野（東工大）液柱塔でどの位粘度の大き い溶液まで測れるか。

答 あまり高粘度の液で測定したことはないが，夜柱 が乱れずにきれいに出来る範囲なら測定可能である。液 柱塔を用いる場合，活とんどが水溶液 (1c.p. 付近)で あるので,このときは問題ないが, 高粘度の夜について もノズルの口径をかえることにより测定が可能であるか も知れない。

澌問 4. 星野（東工大） 溶質を $\mathrm{CO}_{2}$ としているか， 溶質粒子の大きさがはるかに大きい場合には混合物が媒 体の場合でる Stokes-Einstein の式が成立するのではな いか。

答 詳しい検討はしていないか， $\mathrm{C}_{2} \mathrm{H}_{2}, \mathrm{~N}_{2} \mathrm{O}$ などにつ いてやっても $\mathrm{CO}_{2}$ と同様な傾向を示すので，多分成立 しないと思う。

\section{[コメント] アルコール-水系混合溶媒中の抎散係数} について （関大・エ 福島達）

アルコール類水容液中のガスの拡散俰数の推算式には いくつかあるが，代表的なものに次式がある。

$$
D_{1 m} \mu_{1 m}{ }^{n}=x_{2} D_{12} \mu_{12}{ }^{n}+x_{3} D_{13} \mu_{13}{ }^{n}
$$

ここに, $D$ は拡散係数， $\mu$ は粘度， $x$ はモル分率であ る。添字 1,2,3，および $m$ はそれぞれ拡散物質，フルコ 一ル，水扰よび潉合溶媒を表わす。 $n=1$ が Wilke ら (A.I.Ch. E. Journal, 8, 646 [1962]), $n=1 / 2$ क Tang (Ph. D. Dissertation. Texas Univ., 1963) であるが, 图 1,2 と 3,4 に示すように, $D_{12}>D_{13}$ なるエチレンーメタ ノール一水系や二酸化炭素ーエタノールー水系では $n=1 /$ 3， $D_{12}<D_{13}$ なる沃素ーエタノール-ホ素や沃素ーブタ 一ル-水系では $n=1$ の式で推算できそうである。

\section{4-3 非 Newton 流体における抁散係数の推宜法に 関する一考察（東工大·エ 星野定司）}

非 Newton 性高分子水溶液拉よび Slurry 中の低分子 溶質の拡散係数と粘度との関係について, Clough(1962) の考え方を批判し，この埸合にも著者が主張するミクロ 


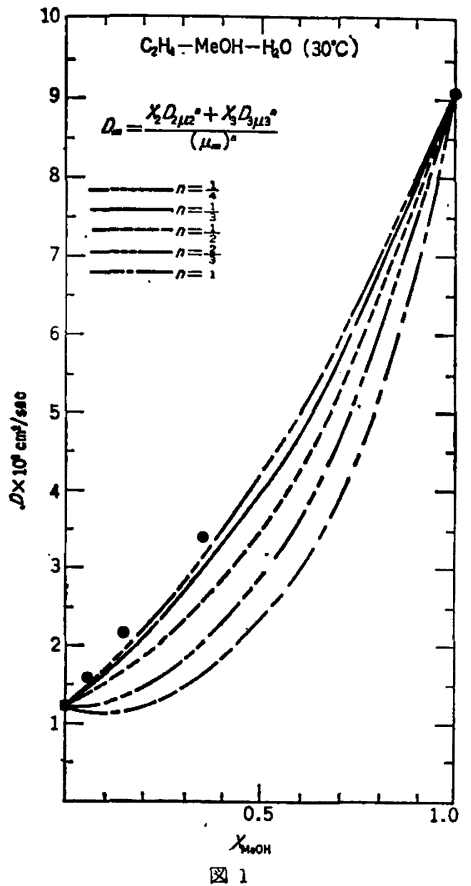

絬度の考え方により，Wilk-Chang 式に実験的補正係数 を加えた式で推算できることを述べた。

Clough が提出した式 $\quad D_{N N}=D_{N} x_{c p \xi \eta} \eta \xi_{c p} \eta_{c p}$ 恃從来の単純な推算法を大幅に改良したが，まだ最大誤 美は $40 \%$ 飞達する。ここに $D_{N N}, D_{N}$ は非 Newton お よび Newton 流体中の拡散係数， $\xi$ は分子間隔 $\lambda$ たけ移 動する間に岦断作用を受ける隣接分子数， クは粘度であ って, 添字 $c p$ は非 Newton 流体中の連続相を示す。著 者は PVP, PVA の水溶液 (Newton 性), CMC 水溶液 (非 Newton 性) 中の尿素, 蔗煻および各種塩類の抎散 係数および当量電導度を測定し，このような場合の拡散 係数 $D$ および当量電導度 $A$ は高分子の種類，払散質の種 類および非 Newton 性か Newton 性か，またそれが拡散 伱数であるか䉓尊度であるかには無関係に純溶媒中の $D$ または $\Lambda$ K汪とんど等しく，高分子䀼度の增大炕よりわ ずか低下するといら結果に基き, Stokes-Einstein 式 $D$ $=k T / \eta$ Kおいて用 へへき粘度》は高分子溶液の粘度 (マク口粘度) ではなく, 純溶媒の粘度（ミクロ粘度） でなければならないことを主張して、この考え方にると ずく次式を提出した。

$$
D=7.4 \times 10^{-8} f(x M)^{1 / 2} T / \eta V^{0.6}
$$

ここに，D梳分子溶液中の低分子溶質の払散係数， $f$ は補正係数で著者の実験データを利用する。他はWilke-

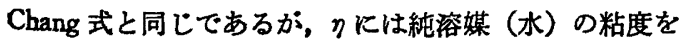
使用する。

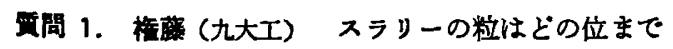
使えるのか。

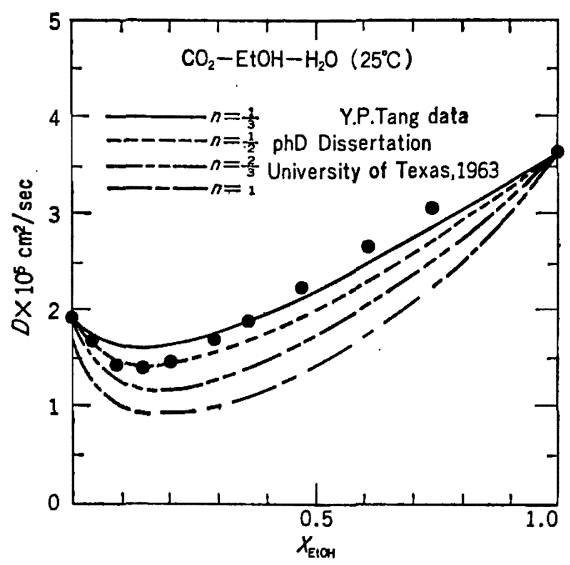

国 2

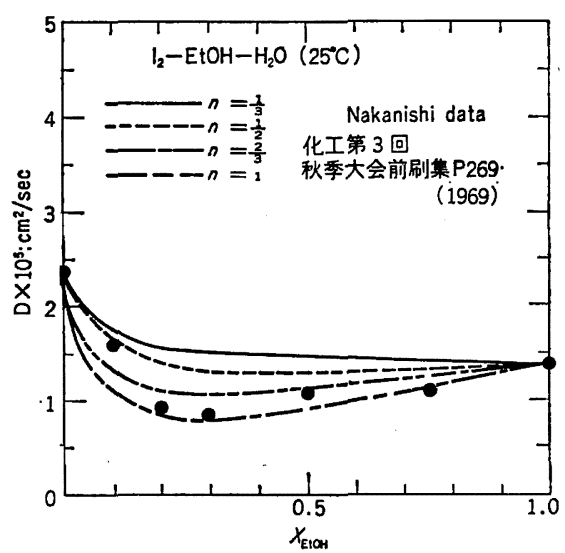

图 3

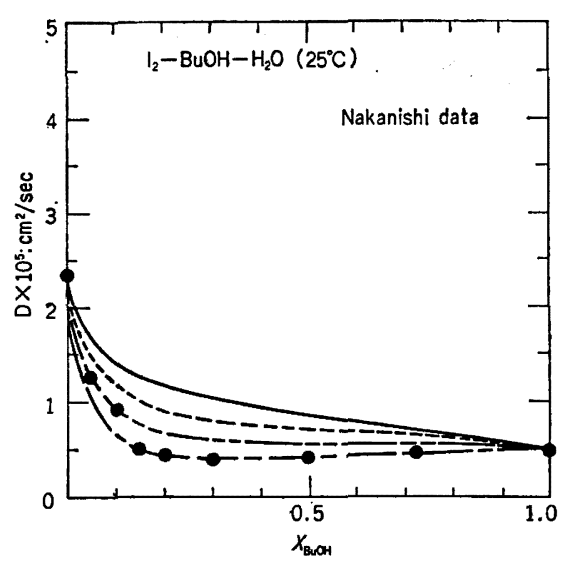

因 4

答 スラリーについてはまだ考えていない。

兵問 2. 佐藤（東理大） 補正係数 $f$ として PVP, PVA 水溶液のデータを提案しているが，非 Newton 性 の CMC 溶液, Kaolinite スラリーにあ使えるか。

答 CMC Kついては電導度の実験で同様の傾向があ 
ったから、これでよいと思う。スラリーについては飛躍 がある。

贾問 3. 佐藤 (東理大) 提案の式中のクはミクロ粘 度と書いてあるが。

答 水の場合にはミクロ粘度はマクロ粘度に等しいか らどちらですよい。ミクロ粘度の定義に含まれる $D_{i n \text { 日, }}$ $/ D_{i n \text { soln }}$ は $f$ のに入っているから, 提案の式中の $\eta$ は 純溶媒の $\eta$ とした方がよい。

票問 4. 椿 (千代田化工建設) 天然ガスの吸収塔の 設計において多成分系のDをどのように考えればよい か。

答 中西 (京大工) 3 成分系でも一つの成分の濃度 が小さいときは 2 成分系と考えてよいと思う。

\section{4-4 フガシチ組成図による相平衡状態の考察 （千代田化工建設 椿 正明）}

演者が 8 月より 2 カ月米国に出張し原稿を人に頼んた 理由もあって, 予稿とは違った講演をされ, 氏自ら後に 述べるような質問を出された。蒸留計算等にたずさわる 設計者は $K$ 值より計算を始め, 平衡関係の研究者はフガ シチまたは活量係数を求めるところで仕事を終え，この 両者間に溝があった。設計方面の関係者は一般にフガシ チに対する理解度が低い等の点から, 学界と産業界の communication の場を求め, 話題を提供したり問題点を 強調することにもシンポジウムの意味があると思うとの 発言があった。

相平衡または蒸留計算で従来気液平衡比や相互溶解度 曲線に基つ゚いて計算していたものを，実験データを一度 Wilson ハラメータ等に還元して各成分のフガシチを計 算し， $\sum\left(f_{i}^{\alpha}-f_{i}^{\beta}\right)^{2}$ を最小にする条件より平衡組成を求 める。こうすることによって多成分系への払張や計算機 による取扱いが容易となり，また単位操作プログラムと の連繋が可能になる等の利点を示した。液々平衡の場 合, Wilsonパラメータを 2 液相のおのおのに応用して, 各種のデータから別々に合計 4 個のパラメータを求めれ ば， 2 液相に分離する系でるWilson の式で推算しらる のではないかと提案した。

犋問 1. 気液平衡ではそれぞれ気相線と液相線があ る。 2 液相分離したとき $L_{1}, L_{2}$ は構造が違5からそれ

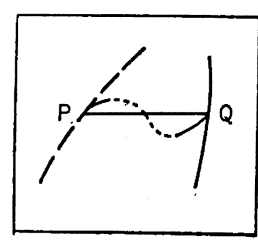

図 5 ぞれ別の線があってよいと思われ るが， $L_{1}$ 相と $L_{2}$ 相は何故 1 本灌 で結ばれるのか。

答 平沼 (苫小牧高専) このこ とは物理現象をモデル化して数学 の場で計算している点を忘れては いけない。したがって, その得ら
れた結果は数学の解で物理現象の解ではないので, 物理 的な解釈によって我々に必要な解を得る必要がある。

斦問 2. 気相-液相を 1 本線で結ぶと何を意味するの か。(国 5 参照)

答 平沼 (苫小牧高専) van der Waalsの式でもでき る通り，過冷却，過熱のゆき過ぎの現象はあるが，㑯斜 が反対のところ (点線) は熱力学的安定性の条件から存 在しない。

留問 3. $\sum x_{i} d \ln \gamma_{i}=0$ の $x_{i}$ は $L_{1}$ 相, $L_{2}$ 相に共通で あるべきか。 $x_{i}=\theta^{L_{1}} x_{i}{ }^{L_{1}}+\theta^{L_{2}} x_{i}{ }^{L_{2}}$ のみかけの組成 $x_{i}$ は どういら意味か。，また，Gibbs-Duhem 式が2 相不連続 のところでも使え， 1 本の山のある曲線で結びっくの か。

答 頼実（広島大） Gibbs-Duhem の式は 2 夜相でな。 く 1 相に対して導かれた式である。

\section{4-5 塩類添加の気液平衡の推算について （名大工恩田格三郎・佐田栄三・大野钽尾）}

$\mathrm{KCl}, \mathrm{NaCl}, \mathrm{CaCl}_{2}, \mathrm{NaNO}_{3}$ の 4 種の塩を水に飽和さ せ,アセトンに微量溶解した場合の蒸気圧と大気圧下の 気液平衡を Othmer 型の装置で測定した。塩の効果を各 成分の蒸気王降下にのみ負わせ, 塩添加のないときの活 量係数 $\gamma_{i}$ と塩を添加した液の蒸気圧 $P_{i}^{3}$ とを用いて $\pi y_{i}$ $=\gamma_{i} P_{i} x_{i}$ より推算すると実测值と平均数\%以内で一致 した。

需問 1. 上西（東北大·非水研） アセトン以外の場 合です蒸気圧を測って本推算法で $y$ の推算が可能か。

答 メタノール, エタノール等に $\mathrm{KCl}$ を入れて测っ たが圧力降下少なく，本推算法でメタノール 70\%以上 の $x$ で一致するが，以下では実測より小さくでた。ェ夕 ノールでは $x=0.5$ 位のところで交叉した。

喻問 2. 仁井田, 栗田(千代田化工建設) 本研究は 特殊な 3 成分系について塩の水溶液を 1 成分とみなし塩 の効果を蒸気圧降下に還元して考える Short-Cut 的取报 い（炭化水素-水系济対する Smith の考え方に類似して いる)をして, 注目するのはアセトンー水の 2 成分として いるが， a）最初から 3 相 3 成分系として取扱うべをと 考える。各 3 相の組成, 純成分の物性值を使用してモデ ルの定式化に進むのでなければ一般的な推算法になり得 ないのではないか。 b) 塩添加によるフガシチの変化が 基礎となるから，塩類不添加の $\gamma_{i}$ を添加した場合に用い るのはきわめて好ましくないと思ら。c）（気相）と（水 トアセトン十塩の相）間に平衡があるように取扱ってい るが, (気相) と（フセトン相）と（水相）のおのおのに fugacity balance が成立するようにすべきでないか。こ らすれば 2 液相のとき成立しない筈の $\pi y_{1}=\gamma_{1} P_{1}{ }^{0} x_{1}\left(P_{1}{ }^{0}\right.$ 
は純粋成分の蒸気王) なる式を用いるなどの無理は生じ ないではないか。

答 御質問はいす゚れす電解質溶液への attack の仕方 の問題であるからまとめてお答えする。

従来より塩を含む系の気液平衡については塩の影響を 塩の存在する場合の $\alpha$ と塩のないとさの $\alpha$ の比に関連つ けて相関して来た。塩を含む場合の気液平術の問題に対 する攻め方として, 従来の考え方と異なり塩の影響を各 成分について考えてみることが必要と思う。その第一段 階として弥気圧降下について検討したが, 報告の多い普 通の気液平衡データを利用して塩添加の場合が比較的よ く推算できれば最も便利だと思うので，塩添加のない場 合の $\gamma$ をいた用いです。すちろん，今回の発表は蒸気圧 降下のみの考慮で比較的よくあった場合で，厳密な推算 をするためにはそれ以外の複雑な影響を検討することが 必要である。この点については検討中である。

[コメント］平沼 (苫小牧高専) 3 成分系で报らと したとき，水の活量係数を $\gamma_{2}{ }^{\prime}=p_{2}{ }^{s} \gamma_{2} / p_{2}{ }^{0}$ と考えた方が よい。

\section{4-6 高正における気液平衡の推算}

（広大工 頼実正弘・吉村尚真・协岡弘勝）

対饦状態原理と仮臨界値を用い Hirschfelder らによ って導かれた状態式によって高圧気液平衡の推算を行な ったのが著者らの従来の研究であった。本講演では対臨 界容積を仮臨界温度と仮臨界圧力との関数として，その 項を導入して気液平衡比を導き(11)式，従来の結果(13) 式と比較検討した。対臨界容積の項を導入しても結果に 大差なく，かえって仮臨界值を求める組合せ方式の方に 誤差の大きな原因のあることが示された。

酘問 1. 上西 (東北大·非水研) 今後の問題の処で る書いて居られるが, 現在までの御研究から従来の式と v。の項を入れた式はそれぞれとな系の推算になら使 用可能か。特に BWR 式の定数が未知の系はどうか。

答 従来の式 (13) と $v_{r}$ の項を入れた (11) 式による 推算は大差なく今のところ優劣は決め難い。筆者らの推 算法に適用される系は主に炭化水素系たか， 2 成分系の 分子の差が大きくなるにれて䛊差む大になる傾向があ る。BWR 定数が不備で，かつ本推算法でよくあう例は 本文中の $\mathrm{N}_{2}+\mathrm{O}_{2}$ 系しか検討していない。

哭問 2. 藩 (東北大工) 現段階で高圧気液平衡を 推算しようとする場合, 状態方程式による方法と, 対応 状態原理を利用する方法に大別される。前者については 簡単な系では BWR 式で推算することが可能であり，ま た, 修正係数を入れることによって臨界点まであ相関が 可能となってきているので，この方法はある程度笑用的
になってきているように思われるが，修正係数の物理的 意味が明確でないため真の意味での推算には限界が感じ られる。これに対し後者の方法は, ある程度分子のオー ダーをでさかのぼって混合物の性質を仮臨界值により表 現し、そのような臨界値をむった仮想純粋物質に対応状 態原理を適用しよらとするすのである。したがって第一 に仮臨界値を求めるここ，第二にその仮臨界值を有する 仮想純粋物質すなわち混合物に対応状態原理を適用する ことから，仮臨界値に如何なる値を与えるかがK值の計 算に大きな影響を与えるものと考える。とくに，仮臨界 值は分子間相互作用にもとつくものであるから，本質的 に混合物の性質を記述する重大なものである。そこで， この仮臨界値の吟味をはなれ，フガシチ係数の表現法の 論議からでは，仮想純粋物質に対応状態原理を適用する 方法の本質的研究の進め方, すなわら真の意味での推算 法にはなり得ないのではないか。この点いかが考えられ ているか。

答（頼実）例えば，最す簡単な 2 成分系の第 2 ビ リアルについて, 1 - 2 間の相互作用でさえ $B_{12}=\sqrt{B_{11} B_{22}}$ と近似しているからここの等式を成立させるための修正 係数の必要なことは当然考えられる。しかし，これは状 態方程式に対するものであるから，むし限界があるとす れば，状態方程式の気液平衡への適用限界に一致させ得 ると考える。つぎに仮臨界値については, 御指摘の通り であるが，従来使用してきた式のみがフガシチ係数を求 める式ではなく，発表のように仮定をかえると v。を導 入した式からでも求められることを示したわけで，仮臨 界值を論ずる以前の問題であると思う。仮臨界値につい ても注意しなければならないことは，BWRの修正係数 と同じ事柄を考えなければならなくなるだろらというこ とである。

常圧における気液平 衡は通常, 活量係数を使用して van Laar, Margules, Wilson などの式で表現している が，これらの定数の決定は 2 成分系であれば，2成分系 気液平衡データを使用して決めている。混合物の性質を 純粋物質の性質のみから推算することは望ましいことた がきわめて困難な事柄で，物性が測定值である以上，推 算とは実測值の数を一つでも少なくする方法であると思 5。

筫問 3. 荒井（東北大工） a）仮臨界值に対する温 度, 王力の影響を考えているか。 b) Leland は $\ln (f / p)$ $=\phi\left(T_{r}^{\prime}, p_{r}^{\prime}, z_{e}^{\prime}\right)(12$ 式）としているか。c) $\ln (f / p)=$ $\phi\left(T_{r}^{\prime}, p_{r}{ }^{\prime}, z_{c}{ }^{\prime}\right), v_{r}=\phi\left(T_{r}^{\prime}, p_{r}{ }^{\prime}, z_{c}{ }^{\prime}\right)$ と状態变数を同し に与えてフガシチ係数の式が哄なるのは熱力学的によい か。d）本方法に混合物の状態方程式を使用するのは何 故か。

答（枷网） a）今のところ考虑していない。将来 は考虑する必要があると思 5。b）御指摘のと扰り式 
（12）に怙いて $z_{e}^{\prime}$ ，式（13）において最後の項（vrを含 む項）は含まれていない。しかしより一般的に扱うた めには第三のパラメータを入れた方がよいと思ったから である。Joffe らの論文 ( $I$ ほ EC, Fundamentals, 5, 455 [1966]）にも第三パラメータとして $z_{c}$ のかわりに偏心 係数 wが考虑されている。c)上く解らないか，式(11) と式 (13) を導く際の出発点として，それぞれ $v=v_{c}{ }^{\prime} \phi$ $\left(T_{r}^{\prime}, p_{r}^{\prime}, z_{c}^{\prime}\right)$ (5式) と（12）式の仮定があり, さ5K 途中に微分, 積分の操作がるので，このような差が出 たと思う。なお，式（11）の最後の［］の中の項がど の上らな意味をもつのかわかっていない。d）御質問の 点が LCG 法と筆者らの方法の相違点の一つである。 LCG 法は基準物質を決め仮臨界值を使って推算を行な らか，基準物質の決め方に橎然としない点があり，また 決めた基準物質によって推算値が異なることがあって, 定量的に满足されるるのではない。定数の混合則を必要 としない点が特徵であるが，基準物質と混合物との対応 状態が必ずしるらまく関係つけられない。Leach らは分 子形状係数を考虑し, 仮臨界値の式をより繁密に定義し てこの方法を発展させている。筆者らのは彼らと異なり， 基準物質を純粋物質に限定せず混合法則を使って仮想 的な混合物があると考えて推算している。故に，むし HBMS式の代りにBWR式を使えば当然 BWR 定数の混 合法則を使うが， BWR 式を使うときは仮臨界値によら ずもとの BWR 式とほとんど差のない結果を得ている。

\section{4-7 二成分系混合物の臨界軌跡の相関法について （東北大·工 荒井康店·巟藤正三郎・前田四郎）}

二成分手臨界点の熱力学的条件は Gibbsによって明ら かにされている。Redlich らは Redlich-Kwong 式を用い て臨界軌跡の両端に和ける勾配を求め適当な関数で内插 している。著者らはBWR 式により両端の勾配を求め, Ackerman らの提唱する内插関数により, 臨界軌跡を求 めた。現段階では 2 成分系混合物の臨界領域まで適用し らる状態方程式が得られないので, BWR 式の定数の混 合則に補正係数 $m$ を入れざるを得ないが, $m$ を $A_{0}$ の 混合則にとり入れて偏倚の大きい系の値を実験值より求 め, Spear らの方法や Chuch らの方法による計算結果と 比較検討した。

賈問 上西 (東北大·非水研) 臨界温度 $T_{\mathrm{c}}$ と臨界圧 カ $P_{c}$ とでは影響する因子が違うと思われるので， $T_{c}$ と $p_{c}$ とでは $m$ が異ってもよいと考えられる。 BWR 式に よる気液平衡推算の場合のように只一個の $m$ で $T_{c}$ と $p_{c}$ も推算できれば非常によいが，この点に対して考えて 牧られるか。

答 気液平衡比 $(K=y / x)$ の実測値を満足するように
BWR 式の $m$ を求めても，混合物の状態を表わす完全 な状態方程式が得られるとは限らないので，その状態方 程式から他の密度 $\rho$ などの物性値を求めても正しい值か 得られないことがある。このような理由で，目的とする $K$ 值, $\rho, T_{c}, p_{c}$ などで $m$ の值が異なることがあってる やむを得ない。この点が気液平衡推算に状態方程式を道 用した場合の限果と考えられる。

\section{4-8 活量係数を用いた液々平街の推算 \\ （苫小牧高事 平沼充安）}

理想性からの偏倚の大きい系の相平衡関係を精度よく 説明したり，推算することは従来困難であったが, 計算 機の発達により複雑な式でる計算の繁雑さが克服された ことと, 僅かの定数のみでかなり高い精度で溶液の平衡 関係を表わすための理論的研究と相まって，かなり精度 よく推算しらるようになった。注目した分子の隣りに, その成分分子がく確率と他の成分分子が来る確率を考 慮に入れた局所モル分率を用いて Renon 5はNRTL式 を導いた。筆者は最近接分子対のもつエネルギーを考え ての局所モル分率より NRTL 式に類似した精度るほ上 んど同様な式を導いた。これらの式を使用して夜々平衡 の実測値と推算値との比較や， Newton-Raphson 法によ る計算法の問題点をあげ， 2 成分定数を無限希釈におけ る活量保数または相互溶解度データから簡単に図上で求 める方法をる紹介した。

要問 1. 石田（哨大工） 新しく導かれた式 (b)と, 前に Guggenheim の理論から導かれた式 (c) によるる のとの推算結果の差はどの程度か。

答 あまりない。しかし (c) 式中の各ハララメータは おの拈の独立でなく，その間に制限があるが，(b) 式で は 3 成分系の 6 個のパラメータ間に何の制限むなく独自 で計算しらる利点はある。今後この問題について研究し てゆきたい。

夏問 2. 長田 (金沢大工) 定温 2 成分采の NRTL 式のパラメータにつき次の $D_{i j}$ を定義する。

$$
\begin{aligned}
& D_{12}=\left(g_{21}-g_{11}\right)-\left(g_{12}-g_{22}\right)=g_{22}-g_{11} \\
& D_{23}=\left(g_{23}-g_{22}\right)-\left(g_{32}-g_{33}\right)=g_{33}-g_{22}
\end{aligned}
$$

とナると

$$
D_{12}+D_{23}=g_{33}-g_{11}
$$

となり、これは $D_{13}$ に外ならない。任意の 3 成分系を構 成する各 2 成分采のバラメータ間に矛盾がないか否か㭘 討するため, $D_{12}+D_{23}$ と $D_{13}$ を実測值より Renon が決 定した結果を, 気液平衡より求めたものと液々平衡より 求めたすので比較した。Renonによれば NRTL 式より 求めた $D$ 值は $100 \mathrm{cal} / \mathrm{mol}$ 程度の誤差を含み, Heil K よるあのは $50 \mathrm{cal} / \mathrm{mol}$, Wilson で $100 \mathrm{cal} / \mathrm{mol}$ といわれ 
ているが，両者の一致したのは 10 例中 2 例だけである。 аをどんな值にしても実測とあわせられ奴系すある。そ の点どのように考えるか。

答 興味ある御意見で，どのように取上げるか迷った か，現在わかることのみ記すと以下のとおりである。 NRTL 式の場合では $g_{i j-g_{y j}}$ の值は $\alpha$ Kす関係するの で、この結果のみでは不一致といえないところがある。 例总ばェタノールー水系では $\alpha$ に無関係によく表わされ るので, もし $\alpha$ を 0.2 0.3 の中間の値をとることで (3) の值と $D_{13}$ を一致させることができる。るっとデータを 検討する必要がある。また，(3) $=D_{12}+D_{23}$ と $D_{13}$ との ハシラメータ間の矛盾の大きさと平衡値推算結果の確度と に直接的関係があれば, 推算結果の評価の一基準になる ので興味がもたれるが，現在入手しているデータの範囲 では直接的関係はない上らに思われる。しかし，さらに 調查したい。

質問 3. 速水（千代田化工建設）液々平衡について は実験設備の簡単さ，測定の容易さから考えて推算方法 をここまで苦労して開発する必要があるかどらか疑問に 感ずる。実際的には測定実験を行なって

(実测 3 成分系データ数点 $\rightarrow$ 全域のデータ推算

実測 3 成分系の相互溶解度データ $\rightarrow$ tie line の推算

の上らな推算方法をさらに開発して欲しいと考兄る。

答 第一にこれらの式の推算精度の検討をすること， 次に可能ならば 3 成分液々平衡データから，おの沶の 2 成分系ハララータを求める方法を考えることなどを考え て行なった。

需問 4. 速水 2 成分系の相互溶解度データから
3 成分系の液々平衡を推算する場合，臨界温度に近い領 域では温度に対する組成の変動が大く，一般的に相互 溶解度の組成の誤差も大となるので推算の精度がおううる ものと考えられる。また，臨界温度から離れた領域では 温度に対し組成の誤差は少ないので推算の精度むあると 考えられる。推算上，この点で問題はなかったか。

答 推算に必要な気液平衡データの場合について, 低 温 $\left(25^{\circ} \mathrm{C}\right)$ 従って減圧下のデータが必要と思われる。今 まで測定されたデータの中では減圧のが少なく，（相互 溶解度 $)+($ 気液平衡 $) \stackrel{\text { 推算 }}{\longrightarrow}$ (液々平衡) ができる場合は少 ない。

質問 5. 椿（千代田化工建設） 2 成分定数が気液平 衡データによるか, 相互溶解度データによるかによって 異なる点について尋ねます。

答 確度の低い式汪ど差が大きい。例えば， Margules の式を使って両者から求めてみるとその差が甚だしい。 しかし, 確度のよい式になるに従って，どちらの方法で 求めたパラメータも一致するようになる。

一般に $x \rightarrow 0$ または $x \rightarrow 1$ になる領域でパラメータの 值に敏感になる。敏感な点でパラメータを決定すること が原則的に好ましいが，この領域は実験精度がおうちるの でこの領域におけるデータが少ないときは別である。

大体以上の上うな講演主旨と質疑応答があったが，現 在に㧍ける物性の推算に関する問題点むかなり明らかに され，会場の雲围気もおかかりいただけたと思う。

\section{[Session 5] 真 空下 の 輸 送 現 象*}

11 月21日（金）：B 会場

座 長 河村祐治・桐栄良三***

\section{まえがき}

異常条件下の操作が総合シンボジウムのテーマとして選ばれ たことは初めてであり, 計画当初発表申込の集りや当日の成果 を幾らか心眍してテーマの幅を大きくとり詳細の制限はつけな

\footnotetext{
*昭和 45 年1月29日 受理

* Yuji Kawamura 仏岛大学工学部 化学工学科

*** Ryozo Toei 京都大学工学部 化学工学科
}

いこととした。真空下の操作はすでに化学工業各方面で工学問”

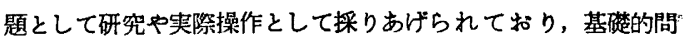
題からトピックスにわたって数多くの発表申込があったことは 幸であった。

今回は流動に関して 3 件, 物質移動に 3 件の発表が行なわれ， 総時間の制約から曊演・討諭時間がかなり制限されることにな ったが，昼の休み時間に 30 分余も延長して䓡心な討議が行なか れ，再度の討諭研究の機会を約して終了した。残った討議は既 設の真空下の輸送現象研究会で続けてゆくつもりであるが,こ の種の問題が追々とテーマに採択されてゆくことが望まれる。 また，少し幅の広いテーマで1日1テーマが適当で，半日で 